\title{
Separation of 2-Methylquinoline from 8-Methylquinoline through Inclusion Complexation with $\alpha$-Cyclodextrin
}

\author{
Isamu UEMASU ${ }^{\dagger 1} *$ and Yukio NAGAO ${ }^{\dagger 2}$ \\ 11) National Research Institute for Pollution and Resources, \\ 16-3 Onogawa, Tsukuba, Ibaraki 305 \\ ${ }^{\dagger 2}$ Sumikin Chemical Co., Ltd., 3 Hikari, Kashima-cho, \\ Kashima, Ibaraki 314 \\ (Received January 21, 1991)
}

\begin{abstract}
Inclusion complexation with $\alpha$-cyclodextrin $(\alpha$-CD) was found to be effective for separating 2 methylquinoline (2-MQ) from 8-MQ. Examination of the $\alpha$-CD-MQ stoichiometric ratios in the complex solids indicated that $1: 1 \alpha$-CD-MQ complex was formed when the molar ratios of MQ to $\alpha$-CD were 4 and 2, and that 2:1 $\alpha$-CD-MQ complex solid was formed when the molar ratio of MQ to $\alpha$-CD was 0.25 . The inclusion selectivity for $2-\mathrm{MQ}$ was higher in the $2: 1$ complex than in the $1: 1$ complex. The results were explained on the basis of the Corey-Pauling-Koltun molecular model.
\end{abstract}

\section{Introduction}

The inclusion complex formation between cyclodextrin $(\mathrm{CD})$ and guest species is said to depend chiefly on the size and shape of the guest ${ }^{1}$. This is the reason that CDs can be used as selective separating agents for disubstituted benzene derivatives etc.

In a previous paper ${ }^{2}$, we showed that the inclusion complexation with $\alpha$-CD was successfully applied to the selective concentration of indole in coal tar. We noticed in the study that quinaldine, i.e., 2-methylquinoline (2-MQ), formed a stable inclusion complex with $\alpha$-CD. Therefore, we presumed that inclusion with $\alpha$-CD might be effective for the separation of 2-MQ from its isomers, especially from 8-MQ.

$2-\mathrm{MQ}$ is a material for producing quinophthalone dyes. It occurs in the crude quinoline fraction obtained from coal tar. 2-MQ is obtained by distilling the crude quinoline. The purity of 2MQ is, at best, about $85 \%$ because of the presence of 8-MQ whose boiling point $\left(247.8^{\circ} \mathrm{C}\right)$ lies very close to that of $2-\mathrm{MQ}\left(247.6^{\circ} \mathrm{C}\right)$. Therefore, ways for separating them are in demand by the industries. Two ways related to the use of inclusion complexation to raise the purity of 2-MQ are presented. One is to use urea which forms an adduct with 2$\mathrm{MQ}^{3}$. The other is to use diol like benzopinacol which forms an inclusion complex solid with 2$\mathrm{MQ}^{4)}$.

In this study we have found that $\alpha-\mathrm{CD}$ is a useful agent for including and separating 2-MQ. It has also been found that the selectivity for including 2-

\footnotetext{
* To whom correspondence should be addressed.
}

MQs is correlated with the stoichiometric ratio of $\alpha$-CD to MQs in the complex.

\section{Experimental}

$\alpha$-CD, $\beta$-CD, 2-MQ, 8-MQ, and 7-MQ were obtained from Tokyo Kasei Kogyo Co., Ltd. Quinoline was purchased from Nakarai Chemicals Ltd. The water used was distilled and deionized. 2. 1 Inclusion Reaction between $C D$ and 1:1 Mixture of 2-MQ and 8-MQ (MQs)

A 1:1 mixture of 2-MQ and 8-MQ was prepared. Four kinds of experiments were carried out by changing the quantities of the MQs mixture added. The molar ratios of total MQs to $\alpha$-CD were $4,2,1$, and 0.5 (see Table 1.).

$\alpha-\mathrm{CD}$ was used always as a $10 \mathrm{wt} \%$ aqueous solution. The MQs mixture was added to it and stirred in a thermostated bath at $25^{\circ} \mathrm{C}$ for $1 \mathrm{~h}$. White solids of $\alpha$-CD inclusion complexes were deposited. They were filtered with a membrane filter (pore size: $0.4 \mu \mathrm{m}$ ), washed with acetone and dried in a desiccator at room temperature for $1 \mathrm{~h}$ under reduced pressure ( 0.5 Torr). Then some of the dried product was weighed and suspended in

Table 1 Inclusion Selectivity and Composition of Complex Solids

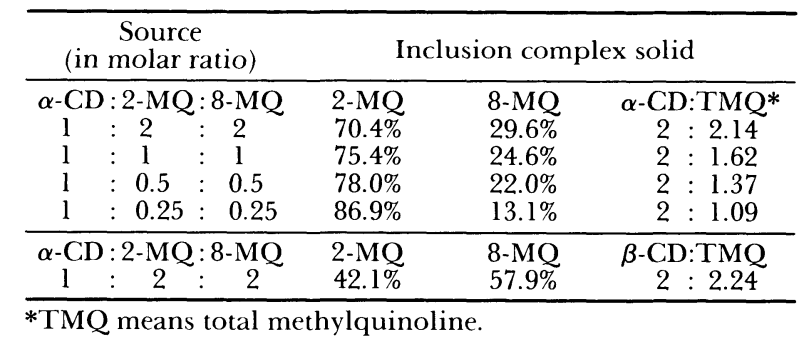

*TMQ means total methylquinoline. 
Table 2 Composition of Inclusion Complex Solid

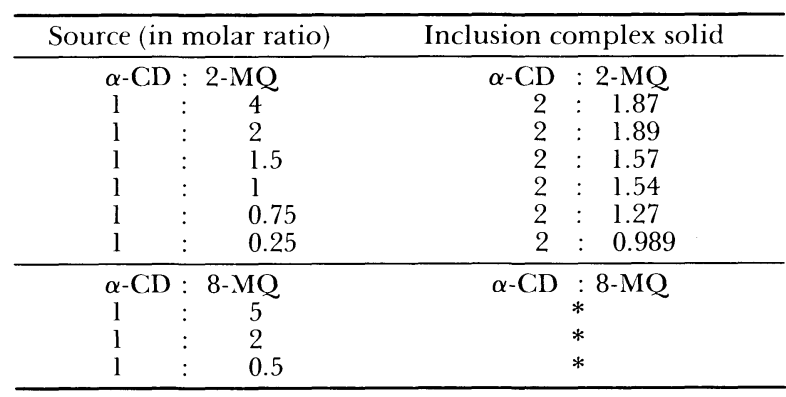

*No solid was deposited.

Table 3 Composition Change Accompanied by Inclusion Complexation

\begin{tabular}{lcc}
\hline & $\begin{array}{c}\text { Crude oil } \\
\text { of 2-MQ }\end{array}$ & $\begin{array}{c}\text { Inclusion } \\
\text { complex }\end{array}$ \\
\hline 2-Methylquinoline & $85.8 \%$ & $93.1 \%$ \\
8-Methylquinoline & $12.3 \%$ & $5.1 \%$ \\
Isoquinoline & $0.1 \%$ & $0.7 \%$ \\
Others & $1.8 \%$ & $1.1 \%$ \\
\hline
\end{tabular}

water. Quinoline was added to the suspension as the internal standard for chromatographic analysis. The mixture was shaken with diethyl ether. Then the inclusion complex was dissociated; the aqueous layer then became a homogeneous and transparent solution of $\alpha$-CD. The MQs and quinoline were transferred to the ether layer. The ether solution was subjected to chromatographic measurements.

For comparison, a similar experiment using $\beta$ CD instead of $\alpha$-CD was carried out. Since the solubility of $\beta$-CD is about $1.8 \mathrm{~g} / 100 \mathrm{~m} l$ water at $25^{\circ} \mathrm{C}$, a $1.5 \mathrm{wt} \%$ aqueous solution of $\beta$-CD was used.

\section{2 Inclusion Reaction of $\alpha$-CD with 2-MQ or 8-MQ}

Several kinds of experiments were carried out by changing the quantity of 2-MQ or $8-\mathrm{MQ}$ added. The molar ratios of $2-\mathrm{MQ}$ to $\alpha$-CD were from 0.25 to 4 and those of $8-\mathrm{MQ}$ to $\alpha$-CD were $0.5,2$, and 5 (see Table 2). The experimental procedure was almost the same as that in 2.1 .

\section{3 Inclusion Complexation between $\alpha-\mathrm{CD}$ and Crude Oil of 2-MQ}

Crude oil of 2-MQ was provided by Sumikin Chemical Co., Ltd.; its composition is shown in Table 3. $0.5 \mathrm{~g}$ of the crude oil was added to $25 \mathrm{ml}$ of a $10 \mathrm{wt} \%$ aqueous solution of $\alpha-\mathrm{CD}$. The mixture was vigorously stirred in a thermostated bath at $30^{\circ} \mathrm{C}$ for $1 \mathrm{~h}$. White solids of $\alpha$-CD inclusion complexes were deposited. They were filtered with a membrane filter (pore size: $0.4 \mu \mathrm{m}$ ), washed with acetone and dried. Then they were suspended in water, and diethyl ether was then
Table 4 Composition Change Accompanied by Inclusion Complexation

\begin{tabular}{lcc}
\hline & Sample oil & Inclusion complex \\
\hline 7-Methylquinoline & $74.6 \%$ & $99.0 \%$ \\
5-Methylquinoline & $24.9 \%$ & $1.0 \%$ \\
Others & $0.5 \%$ & $0 \%$ \\
\hline
\end{tabular}

added. After shaking the mixture for a while, the guest species included were extracted into the ether layer. Evaporation of ether gave an oil in which 2-MQ was selectively concentrated.

\section{4 Inclusion Concentration of 7-MQ}

The 7-MQ reagent used here consisted of about 75\% of 7-MQ and 25\% of 5-MQ as shown in Table 4.

$0.30 \mathrm{~g}$ of the reagent was added to $5 \mathrm{ml}$ of a $10 \mathrm{wt} \%$ aqueous solution of $\alpha$-CD. The subsequent procedure was the same as described in 2. 1.

\section{5 Chromatographic Measurement of Organic Components}

The composition of organic compounds was determined with a GC-9A gas chromatograph (Shimadzu Corporation) with a fused-silica wallcoated capillary colum ( $50 \mathrm{~m} \times 0.25 \mathrm{~mm}$ I.D.) using $\mathrm{OV}-\mathrm{l}$ as the liquid phase under the conditions as follows: carrier gas, He; flow rate $0.6 \mathrm{ml} / \mathrm{min}$; injection port temperature, $300^{\circ} \mathrm{C}$; sample size, $0.4-5 \mu l$; splitting ratio, 1:50; flame ionization detector; column temperature, $130^{\circ} \mathrm{C}$ for $23 \mathrm{~min}$ then increased to $200^{\circ} \mathrm{C}$ at a rate of $5^{\circ} / \mathrm{min}$. Under such conditions, the retention times were $14.6 \mathrm{~min}$ for quinoline, $18.9 \mathrm{~min}$ for $2-\mathrm{MQ}$, $20.2 \mathrm{~min}$ for $8-\mathrm{MQ}, 22.7 \mathrm{~min}$ for $7-\mathrm{MQ}$, and $24.1 \mathrm{~min}$ for $5-\mathrm{MQ}$.

In the eexperiments of $\mathbf{2 . 1}$ and 2.2, the compositions were calculated reducing the peak area to the mass of each compound using quinoline as the internal standard. In the experiments of $\mathbf{2 . 3}$ and 2. 4, the compositions were simply calculated from the chromatographic peak area of each compound.

\section{Results and Discussion}

Table 1 shows that 1:1 $\alpha$-CD-MQ complex solids were formed when the molar ratio of total MQs, meaning 2-MQ and 8-MQ, to $\alpha-\mathrm{CD}$ was 4 and that 2:1 $\alpha$-CD-MQ complex solid was formed when the molar ratio of total MQs to $\alpha-\mathrm{CD}$ was 0.5 . When the molar ratios were 2 and 1, the complex solids seem to be the mixtures of $1: 1$ and 2:1 CD-MQ complexes. Furthermore, Table 1 shows that inclusion selectivity for guest species is correlated with the stoichiometric ratio of $\alpha$-CD to MQ in the complex solids, i.e., the inclusion selectivity for 2MQ was higher in the 2:1 complex than in the $1: 1$ complex.

Compared with $\alpha-\mathrm{CD}, \beta-\mathrm{CD}$ did not show any remarkable selectivity for including $2-\mathrm{MQ}$ or 8 - 
MQ. The analysis of the stoichiometric ratio indicates that $\beta$-CD forms $1: 1$ complex with MQs.

Table 2 indicates that 1:1 $\alpha$-CD-2-MQ complex solid was formed when the molar ratios of $2-\mathrm{MQ}$ to $\alpha$-CD were 2 and 4 and that 2:1 complex solid was formed when the molar ratio of 2-MQ to $\alpha$-CD was 0.25 . When the molar ratios of $2-\mathrm{MQ}$ to $\alpha$-CD were $0.75,1$, and 1.5 , the complex solids seem to be the mixtures of $1: 1$ and 2:1 complex solids. The results are similar to those shown in Table 1.

Solid of $\alpha$-CD-8-MQ complex was not obtained regardless of the amount of $8-\mathrm{MQ}$ used for $\alpha$-CD complexation. When a mixture of $\alpha$-CD aqueous solution and $8-\mathrm{MQ}$ was stirred vigorously, the mixture became emulsified and opaque. When the resulted emulsion was left standing for half an hour, it became a transparent liquid containing some drops of 8-MQ, and no solid was deposited.

This result seems to be inconsistent with the fact that solid $\alpha$-CD-8-MQ complex was produced by the reaction of $\alpha-\mathrm{CD}$ with a $2-\mathrm{MQ}$ and $8-\mathrm{MQ}$ mixture. A similar phenomenon was observed in the complexation with 1-methylnaphthalene (1$\mathrm{MN}$ ) and 2-MN in which a complex solid of 1-MN was produced by the reaction of $\alpha$-CD with a $1-\mathrm{MN}$ and 2-MN mixture, while it was not obtained by the reaction of $\alpha$-CD with pure 1-MN. Causes for such phenomena have not yet been clarified.

Although we still have not examined the reaction of $\alpha$-CD-MQs in dilute solution systems, $1: 1$ and 2:1 complexes must be present in the solution phase. It is natural that such complexes exist in the solution since the presence of both $1: 1$ and 2:1 complexes of $\alpha$-CD with quinoline or isoquinoline has been reported ${ }^{5}$.

The results of inclusion selectivity can be well explained by the result of above-mentioned stoichiometric ratio analysis and by the Corey-Pauling-Koltun (CPK) molecular model. According to the CPK model, the heterocyclic part of methylquinoline (see Fig. 1) can be included completely in the pore of $\alpha$-CD. Since the methyl group at 2-position does not cause much steric hindrance and that at 8-position hinders a deep inclusion, 2-MQ can be included by $\alpha$-CD more firmly than $8-\mathrm{MQ}$. One $2-\mathrm{MQ}$ molecule can be included more firmly by two $\alpha$-CD molecules than 8-MQ since the methyl group at 8-position causes

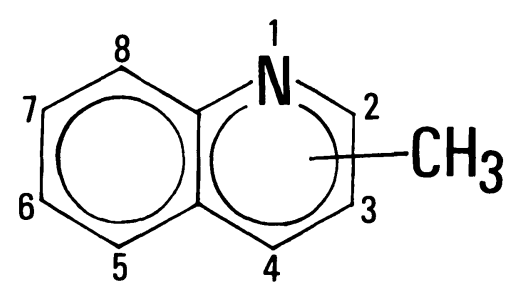

Fig. 1 Monomethylquinoline Isomer

great steric hindrance to the inclusion by second $\alpha$ $\mathrm{CD}$ molecule. The steric effect seems to be more obvious in the 2:1 complex than in the $1: 1$ complex. This is consistent with the experimental result that the inclusion selectivity for $2-\mathrm{MQ}$ was higher in the 2:1 complex than in the $1: 1$ complex (see Table $\mathbf{1}$ ).

As for $\beta$-CD, its pore is about $2 \AA$ greater in diameter than that of $\alpha-\mathrm{CD}$, and both $2-\mathrm{MQ}$ and 8 MQ can be included without steric hindrance. Therefore, no remarkable selectivity for including 2-MQ or 8-MQ was observed as shown in Table 1.

As can be seen in Table 3, the use of $\alpha-\mathrm{CD}$ as a separating agent was effective for crude oil of 2MQ.

From the viewpoint of molecular size and shape, 7-MQ and 5-MQ appear to correspond to 2-MQ and 8-MQ, respectively (see Fig. 1). Therefore, we have attempted to separate $7-\mathrm{MQ}$ and $5-\mathrm{MQ}$. Table 4 shows that $7-M Q$ was concentrated very selectively in the $\alpha$-CD complexes ${ }^{6}$. This result supports our explanations above-mentioned based upon the CPK model.

\section{References}

1) Bender, M. L., Komiyama, M., "Cyclodextrin Chemistry”, Springer-Verlag, Berlin (1978).

2) Uemasu, I., Nakayama, T., J. Inclus. Phenom. and Molec. Recogn. Chem., 7, 327 (1989).

3) Jpn. Kokai Tokkyo Koho JP 57 114,574 [82 114,574].

4) Jpn. Kokai Tokkyo Koho JP 61 93,165 [86 93,165].

5) Wong, A. B., Lin, S.-F., Connors, K. A., J. Pharm. Sci., 72, 388 (1983).

6) This seems very useful for obtaining 7-MQ of high purity. To our knowledge, the commercially available reagent of 7 -MQ usually includes about $20-25 \%$ of 5 -MQ except the reagent of Aldrich Chemical Co. 
要 旨

\section{$\alpha$-シクロデキストリンの包接錯体生成を用いる}

2-メチルキノリンと 8-メチルキノリンの分離

上栘 勇 ${ }^{\dagger 1)}$, 長尾 幸生 ${ }^{\dagger 2)}$

†1）...業技術院公害資源研究所，305 茨城県つくば市小野川 16-3

†2) 住金化 $\mathrm{I}^{-}$(株), 314 茨城県鹿島郡鹿島町大字光 3 番地

$\alpha$-シクロデキストリン $(\mathrm{CD})$ による包接錯体生成を利用し て，2-メチルキノリン $(\mathrm{MQ})$ と 8- $\mathrm{MQ}$ の分離が有効に行え ることがわかった。錯体固体の $\alpha-\mathrm{CD}-\mathrm{MQ}$ 量論比を検討した ところ，ゲスト種が $\alpha-\mathrm{CD}$ に対し 4 倍モル，2 倍モルあるとき
は $1: 1 \alpha-\mathrm{CD}-\mathrm{MQ}$ 錯体が生成し，ゲスト種が $\alpha-\mathrm{CD} の 0.25$ 倍モルのときは $2: 1$ 錯体が生成した。2-MQに対する包接選 択性は, $2: 1$ 錯体の方が 1:1 錯体の場命よりも高かった。 Corey-Pauling-Koltun 分子模型に基づき，結果を説明した。

\section{Keywords}

$\alpha$-Cyclodextrin, Monoethylquinoline isomer, Inclusion complex, Separation, Inclusion selectivity 